Journal of Engineering Sciences, Assiut University, Vol. 41 No. 1 pp.1-19 - January2013

\title{
NUMERICAL SIMULATION OF FLOW AND LOCAL SCOUR AT TWO SUBMERGED-EMERGENT TANDEM CYLINDRICAL PIERS
}

\author{
Hassan I. Mohamed
}

Associate Professor, Civil Engineering Dept., Assiut University, Assiut 71516,

Egypt. E-mail: hassanmohamed_2000@yahoo.com

(Received June 25, 2012 Accepted July 29, 2012)

\begin{abstract}
In this paper, the flow and local scour variation around two submerged and un-submerged tandem piers are studied using $3 D$ flow model where the upstream pier is submerged while the downstream pier is emergent. The model uses a finite-volume method to solve the non-transi ent Navier-Stokes equations for three dimensions on a general non-orthogonal grid. The $k-\varepsilon$ turbulence model is used to solve the Reynolds-stress term. The numerical model solves the sediment continuity equation in conjunction with van-Rijn's bed-load sediment transport formula to simulate the bed evolution. The $3 D$ flow model is verified through experimental study in a non cohesive bed material in an experimental flume. The different causes of local scour around two submerged and unsubmerged piers are simulated well, such as bow flow, down flow, horseshoe vortex, pressure variation and lee-wake vortex. It is found from this study that the maximum local scour depth by interaction between two tandem submerged unsubmerged piers depends on submersion ratio of upstream pier, the densimetric Froude number, the longitudinal distance between piers and the ratio of pier diameter to channel bed width. The maximum scour depth decreases by increasing the submerged pier height then begin to increase by increasing the submerged pier to a height larger than half the water depth and in general the maximum scour depth is less than that of two unsubmerged piers. The results show good agreement between simulation and experimental results. Also, empirical equations are developed for computing the maximum scour depth due to the interaction between two submerged unsubmerged piers with circular shapes as a function of submergence ratio, piers spacing, densimetric Froude number and channel width to pier diameter ratio.
\end{abstract}

Keywords: Numerical Modeling, Flow, Local Scour, Double Bridge Piers, $k-\varepsilon$ Turbulence Model.

\section{NOMENCLATURE}

The following symbols are used in this paper:

$B=$ channel width

$c_{\varepsilon 1}, c_{\varepsilon 2}, c_{\mu}=$ constants in $k-\varepsilon$ model

$D=$ pier diameter $p_{k}=$ production of turbulent kinetic energy

$Q=\operatorname{dish} \arg e$

$U=$ mean velocity 
$d_{s}=$ maximum scour depth

$u=$ fluctuating velocity

$d_{50}=$ bed sediment grain size at $50 \%$ passing

$t=$ time

$F_{e}=$ Froude number

$x=$ length scale

$g=$ acceleration of gravity

$\delta_{i j}=$ Kronecker delta

$h$ = water depth

$\varepsilon=$ turbulent dissipation of $k$

$k=$ turbulent kinetic energy

$v_{T}=$ turbulent eddy viscosity

$L=$ spacing between centerlines of the piers

$\rho=$ density of water

$p=$ pressure

$\sigma_{k}, \sigma_{\varepsilon}=$ constant in $k-\varepsilon$ model

\section{INTRODUCTION}

There are many situations at which the pier becomes submerged. For example, a bridge pier gets submerged when it receives a high flood during its construction, Dey et al. [1]. Also, sometimes a structure constructed along the riverbanks for the bank protection behaves as if it were a submerged structure during floods. Additionally, in coastal and offshore engineering, submerged finite structures are often exposed to the flow (tides and currents), Zhao et al. [2]. In addition in real engineering applications generally the piers may be founded on foundations with larger dimensions that are totally submerged in water. Also, a caisson may be placed around the pier for scour protection. Many researchers studied the turbulent flow around submerged cylinders among of them Palau-Salvador et al. [3], Stoesser et al. [4], Hsu et al. [5] and Lee and Mizutani [6]. However it will be demonstrated that up to date there is very little knowledge available about the interaction between the flow and local scour around submerged cylinder. No experimental or sufficient numerical studies so far have been carried out for flow and local scour around a group of submerged and unsubmerged structures founded on a bed. The complex three-dimensional flow and sediment transport around such structures have defied an analytical solution to the problem and there are wide divergences in scour depths estimated through the available empirical and semi-empirical methods. The time consuming and expensive nature of experimental research on scouring processes caused by flowing water makes it attractive to develop numerical tools for the prediction of the interaction of the fluid flow and the movable bed. Hence flow and local scour around a tandem submerged emergent structures mounted on a bed is investigated numerically in this research.

Yasunori [7] have conducted laboratory experiments on local scour around a submerged pier and concluded that the shape of the scouring hole in the submerged conditions is similar to that in the non-submerged condition and the maximum scour depth reduces as the height of the pier decreases. Sadeque et al. [8], [9], [10] divided the flow around submerged cylinder to four regimes; deeply submerged object (submergence ratio $h / P \cong 4$ ); moderately submerged object $(h / P \cong 2$ ); slightly submerged object $(h / P \cong 1.1)$ and nonsubmerged object $(P>h)$ where $h$ is the mean water depth and $P$ is submerged pier height. Euler and Herget [11] developed a simple process-based approach based on the obstacle Reynolds and Froude numbers to determine the local scour at submerged cylinders. They showed that the size of the projected frontal obstacle area in relation to the mean flow velocity has a significant 
effect on the scour hole shape and depth. Dey et al. [1] introduced a submergence factor to determine the scour depth at a submerged cylinder from information of the scour depth at an unsubmerged cylinder of the same diameter. Amini et al. [12] proposed empirical relations to predict the effect of pile group arrangements, pile spacing, and submergence ratio on scour depth. Zhao et al. [13] studied experimentally local scour around subsea caisson structures. It was found from the test results that the horseshoe vortex played a less important role compared with the velocity amplification at the sharp corners of the caisson if its height is smaller than its horizontal dimension. Shamloo et al. [14] carried out laboratory study on the flow and erosion around simple habitat structures. It was found that the relative depth of flow is the important parameter for the flow regime around habitat structures.

In recent years, several numerical models have been constructed for simulating 3D flow field and/or bed variations around circular piers. Richardson and Panchang [15] used a 3D transient model to compute the flow field around a pier within a given fixed scour hole. Without modeling sediment transport, they estimated the depth of equilibrium scour simply by means of lagrangian particle-tracking analysis. By incorporating various sediment transport models, a few researchers have developed scouring models with various features. Abouzeid et al. [16] studied numerically using 3D flow model flow and clear water scour by interaction between bridge piers. They concluded that the maximum scour depth at multiple bridge piers is largely affected by the ratio of pier diameter to channel width, longitudinal spacing between piers, Froude number and bed sediment size. Tseng et al. [17] investigated numerically the 3D turbulent flow field around square and circular piers. The simulated results indicated that the velocity and shear stress around the square pier were significantly higher than those around the circular pier. Yen et al. [18] developed a morphological model consisting of a 3D flow model and a scour model to simulate the bed evolution around a circular pier. The large eddy simulation approach is employed to compute 3D flow velocity and bed shear fields.

According to the aforementioned researches, it can be seen that so far no experimental or numerical studies have been carried out for flow and local scour around a tandem submerged emergent two cylinders mounted on a bed. Wide applications of this type of structure require a better understanding of flow and local scour around it. This paper presents the findings of numerical and experimental investigations for the flow and local scour due to interaction of two submerged emergent circular piers for steady flow under condition of clear water scour.

\section{MODEL DESCRIPTION}

The computational fluid dynamics code used for this investigation was developed by Olsen [19]. The model has been applied to a number of engineering situations including flow modelling for estimation of spillway capacity, (Olsen and Kjellosvig [20]), simulation of water and sedimentation in a sand trap, (Olsen and Skoglund [21]), simulation of scour around a cylinder, (Olsen and Kjellesvig [22]), and simulation of flow dynamics in a river with large roughness elements, (Olsen and Stokseth [23]). The code solves the Navier-Stokes equations with a $k-\varepsilon$ turbulence closure model on a three-dimensional non-orthogonal grid. This software employs the Navier-Stokes equations for turbulent flow in a general three-dimensional geometry: 


$$
\frac{\partial U_{i}}{\partial t}+\mathrm{U}_{\mathrm{j}} \frac{\partial \mathrm{U}_{\mathrm{i}}}{\partial \mathrm{x}_{\mathrm{j}}}=-\frac{1}{\rho} \frac{\partial}{\partial \mathrm{x}_{\mathrm{j}}}\left(\mathrm{p} \delta_{\mathrm{ij}}+\rho \overline{u_{i} u_{j}}\right)
$$

Where $\mathrm{U}_{\mathrm{i}}$ is the local velocity; $\mathrm{x}_{\mathrm{j}}$ is space dimension; $\delta_{\mathrm{ij}}$ is Kronecker delta (if $\mathrm{i}=\mathrm{j}$ then 1 , else 0 ); $\rho$ is fluid density; $p$ is pressure; and $\overline{u_{i}}$ is the averaged velocity.

A control-volume approach is used for discretization of the equations. The default mechanism for pressure correction is the SIMPLE method, Patanker [24]. This is used for coupling of all cells except those closest to the surface and allows calculation of a free water surface. For these cells, the continuity of water was used to calculate movement of the water surface. The numerical models and the discretization of the equations are described in more details by Rodi [25], Patanker [24], and Melaaen [26]. The $k-\varepsilon$ model is used to calculate the turbulent shear stress for three-dimensional simulations. The eddy-viscosity concept with the $k-\varepsilon$ model is used to model the Reynolds stress term as illustrated in Eq. (2) (where the first term on the right-hand side of the equation forms the diffusive term in the Navier-Stokes equation):

$$
-\overline{\mathrm{u}_{\mathrm{i}} u_{j}}=v_{T}\left(\frac{\partial U_{\mathrm{i}}}{\partial \mathrm{x}_{\mathrm{j}}}+\frac{\partial U_{\mathrm{j}}}{\partial \mathrm{x}_{\mathrm{i}}}\right)-\frac{2}{3} k \delta_{\mathrm{ij}}
$$

The $k-\varepsilon$ model simulates the eddy-viscosity as:

$$
v_{T}=\mathrm{C}_{\mu} \frac{\mathrm{k}^{2}}{\varepsilon}
$$

Where $k$ is the kinetic energy as defined by;

$$
k=\frac{1}{2} \overline{\mathrm{u}_{\mathrm{i}} u_{j}}
$$

$k$ is modelled as:

$$
\frac{\partial k}{\partial t}+\mathrm{U}_{\mathrm{j}}\left(\frac{\partial k}{\partial x_{j}}\right)=\frac{\partial}{\mathrm{x}_{\mathrm{j}}}\left(\frac{v_{T}}{\sigma_{k}} \frac{\partial k}{\partial x_{j}}\right)+\mathrm{p}_{\mathrm{k}}-\varepsilon
$$

Where $p_{k}$ is given by:

$$
p_{k}=v_{\mathrm{T}} \frac{\partial \mathrm{U}_{\mathrm{i}}}{\partial \mathrm{x}_{\mathrm{j}}}\left(\frac{\partial \mathrm{U}_{\mathrm{j}}}{\partial \mathrm{x}_{\mathrm{i}}}+\frac{\partial \mathrm{U}_{\mathrm{i}}}{\partial \mathrm{x}_{\mathrm{j}}}\right)
$$

and $\varepsilon$ is modelled as

$$
\frac{\partial \varepsilon}{\partial t}+\mathrm{U}_{\mathrm{j}} \frac{\partial \varepsilon}{\partial \mathrm{x}_{\mathrm{j}}}=\frac{\partial}{\partial \mathrm{x}_{\mathrm{j}}}\left(\frac{\nu_{T}}{\sigma_{\varepsilon}} \frac{\partial \varepsilon}{\partial \mathrm{x}_{\mathrm{j}}}\right)+\mathrm{c}_{\varepsilon 1} \frac{\varepsilon}{k} p_{\mathrm{k}}-\mathrm{c}_{\varepsilon 2} \frac{\varepsilon^{2}}{k}
$$

The equations contain five constants which are implied in the used program as, (Olsen [19]): $\mathrm{c}_{\mu}=0.09 ; \mathrm{c}_{\varepsilon 1}=1.44 ; \mathrm{c}_{\varepsilon 2}=1.92 ; \sigma_{\mathrm{k}}=1.0 ;$ and $\sigma_{\varepsilon}=1.3$. 
The influence of rough boundaries on fluid dynamics is modelled through the inclusion of the wall law:

$$
\frac{U}{U_{*}}=\frac{1}{K} \ln \left[\frac{30 \mathrm{z}}{\mathrm{k}_{\mathrm{s}}}\right]
$$

As it is given by Schlicting [27], The variable $\mathrm{k}_{\mathrm{s}}$ equals to the roughness height, $K$ is von Karmen constant, $U$ is the mean velocity, $U_{*}$ is the shear velocity and $\mathrm{z}$ is the height above the bed. Boundary shear stress is calculated as:

$$
\tau=0.3 \rho k
$$

This approach is the one, which used by Olsen and Kjellesvig [20] and Olsen and Skoglund [21] and assume that turbulent kinetic energy is the driver for boundary shear stress. In open cells, turbulent kinetic energy can be advected with the flow and dissipated to adjacent cells. However, energy cannot pass through bed cells and is assumed to be transferred from kinetic energy to a force in the form of boundary shear stress. Using this approach boundary shear stress is principally determined by shear near bed through Eqs. (5) and (6).

\section{Calculation of Sediment Transport:}

Sediment is transported as bed load and suspended load. The suspended load can be calculated with the convection-diffusion equation,

$$
U_{j} \frac{\partial c}{\partial x_{j}}+w\left(\frac{\partial c}{\partial x_{z}}\right)=\frac{\partial}{\partial x_{j}}\left(\Gamma \frac{\partial c}{\partial x_{j}}\right)
$$

in which $\mathrm{c}=$ sediment concentration and $\mathrm{w}=$ fall velocity of sediment particles. The diffusion coefficient $\Gamma$ was obtained from the $k-\varepsilon$ model:

$$
\Gamma=\frac{v_{\mathrm{T}}}{S_{c}}
$$

The Schmidt number $S_{c}$ is assumed to be unity in this study. Eqn. (10) was discretized with a control volume approach.

The bed load can be simulated with bed load equation. However, the existing bed load equations are developed for one-dimensional uniform flow. For a threedimensional flow situation, van Rijn [28] developed a formula in which the bed load was calculated as a concentration in the elements closest to the bed. The suspended load calculation also needs a formula for the concentration at the bed. If this formula is the same as the formula for simulating the bed load, it is possible to simulate both bed load and suspended load at the same time. Then interaction between bed load and suspended load is also simulated. Van Rijn's [28] formula for bed concentration is given as

$$
c_{\text {bed }}=0.015 \frac{d_{50}}{a} \frac{\mathrm{T}^{1.5}}{D^{* 0.3}}
$$

in which $a=$ a reference level, set to $1.5 \%$ of the water depth. 


$$
\begin{aligned}
& \mathrm{T}=\frac{\tau_{0}-\tau_{\text {critical }}}{\tau_{\text {critical }}} \\
& D^{*}=d_{50}\left[\frac{\left(\rho_{s}-\rho_{w}\right) g}{v^{2}}\right]^{1 / 3}
\end{aligned}
$$

Where $\tau_{0}=$ bed shear stress; $\tau_{\text {critical }}=$ critical bed shear stress; $\rho_{w}$ and $\rho_{s}=$ density of water and sediment respectively; $v=$ viscosity of the water, and $g$ =acceleration of gravity.

\section{Grid Construction:}

A structured grid mesh on the x-y-z plane was generated. As shown in Figure (1), a three dimensional grid mesh with 136 elements in the $x$-direction, 40 elements in the $y$ direction and 14 elements in the z-direction. An uneven distribution of grid lines in both horizontal and vertical directions was chosen in order to keep the total number of cells in an acceptable range and to get valuable results in the area around the cylinders. The following grid line distributions were chosen: in $\mathrm{x}$-direction: 10 cells with a 0.04 $\mathrm{m}, 5$ cells with a $0.01 \mathrm{~m}, 50$ cells with a $0.005 \mathrm{~m}$ and 71 cells with a $0.05 \mathrm{~m}$ respectively. In y-direction: 10 cells with a $0.01 \mathrm{~m}, 20$ cells with a $0.005 \mathrm{~m}$ and 10 cells with a $0.01 \mathrm{~m}$ respectively. In z-direction: 6 cells with $5 \%$ height of the water depth and 7 cells with $10 \%$ of the water depth.

The circular piers was generated by specifying its ordinates, then the grid interpolated using the elliptic grid generation method as shown in Figure (2).

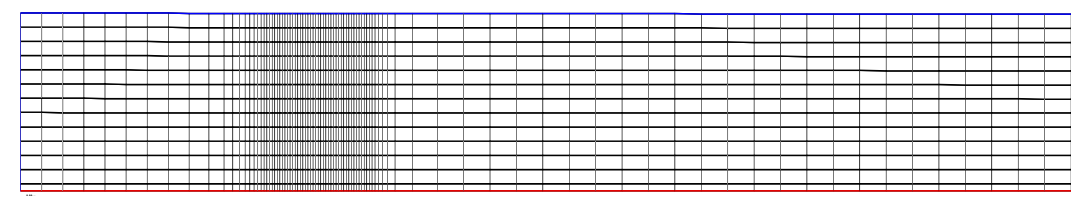

(a) xz-plane for computational grid

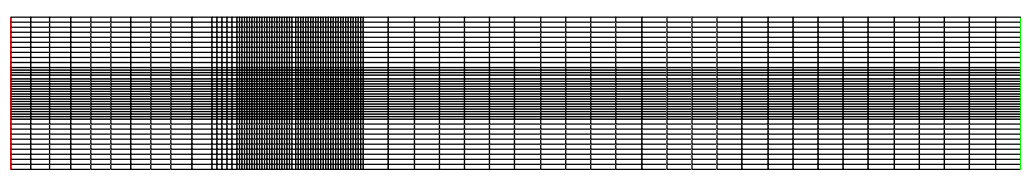

Figure 1 (b) xy-plane for computational grid 


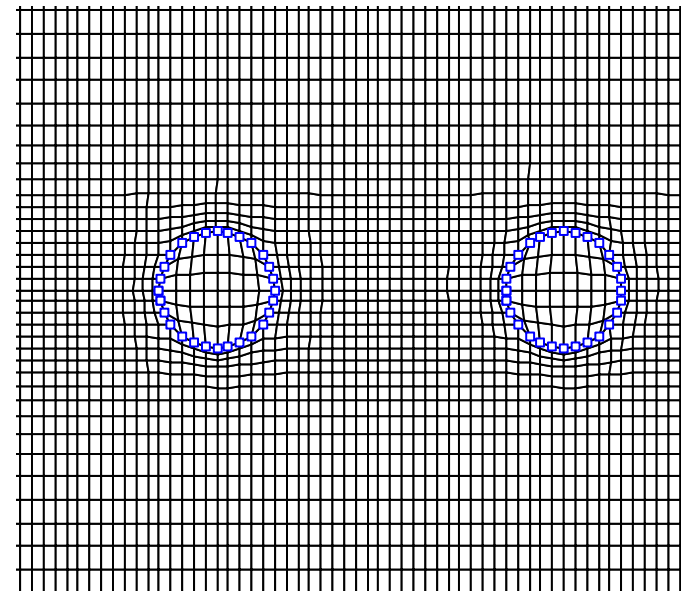

Figure 2 Detailed view of the grid after piers generation

The only boundary conditions, that were specified, were the water discharge, the geometry and the initial water level, boundary roughness and sediment size. The upstream boundary condition was given by the mean approach flow velocity. Zero gradient boundary conditions at the downstream boundary had to be given to prevent instabilities. This meant that the water discharge at the downstream boundary was not specified.

\section{EXPERIMENTAL WORK}

Particular experiments were conducted in an open rectangular tilting flume with a length of $17.5 \mathrm{~m}$, width of $0.3 \mathrm{~m}$ and depth of $0.5 \mathrm{~m}$ to verify the numerical results. Experiments were carried out under the condition of clear water scour. Table (1) shows the range of variables used in the experiments and Figure (3) shows schematic sketch for the variables. The flume bed was covered by clean angular sand particles with $\mathrm{d}_{50}=$ $0.78 \mathrm{~mm}$ and geometric standard deviation of particle, $\sigma_{\mathrm{g}}=1.64$ for a thickness of 20 $\mathrm{cm}$. Test section located $6 \mathrm{~m}$ away from the upstream end. A false floor was constructed along the length of the flume $0.20 \mathrm{~m}$ above the bottom. The experiment was started by carefully filling the flume with water to the required flow depth. This was done with great care so as not to cause too much disturbance to the flow. Two point gauges of $0.1 \mathrm{~mm}$ accuracy were used for measuring water depth in the longitudinal direction and the profile of the scour hole. Each experiment was stopped after a period of about 4 hours. 
Table 1 Range of variables for laboratory experiments

\begin{tabular}{|c|c|c|c|c|c|}
\hline Parameter & Symbol & Value & \multicolumn{2}{|c|}{ Range } & \multirow{2}{*}{ Units } \\
\cline { 4 - 5 } & & & From & To & \\
\hline Pier diameter & $\mathrm{D}$ & 50 & - & - & $\mathrm{mm}$ \\
\hline Discharge & $\mathrm{Q}$ & varied & 8.36 & 10.47 & $\mathrm{~L} / \mathrm{s}$ \\
\hline $\begin{array}{c}\text { Mean water } \\
\text { depth }\end{array}$ & $\mathrm{h}$ & varied & 9.6 & 16 & $\mathrm{~cm}$ \\
\hline $\begin{array}{c}\text { Submerged pier } \\
\text { height }\end{array}$ & $\mathrm{P}$ & $3,6,10$ & 3 & 10 & $\mathrm{~cm}$ \\
\hline Froude number & $\mathrm{Fe}$ & Varied & 0.148 & 0.32 & - \\
\hline Pier spacing & $\mathrm{L} / \mathrm{D}$ & Varied & 3 & 5 & - \\
\hline Sediment size & $\mathrm{d}_{50}$ & 0.78 & - & - & $\mathrm{mm}$ \\
\hline
\end{tabular}

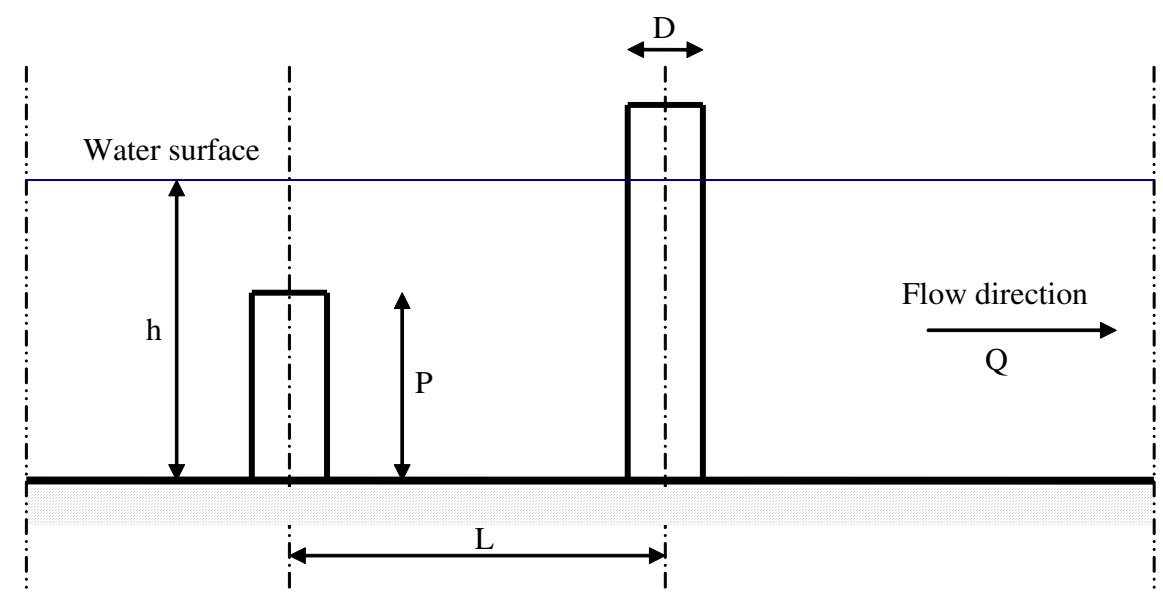

Figure 3 Schematic sketch for the variables

\section{MODEL VERIFICATION}

Series of tests were performed on a two tandem piers of varies spacing. In all runs, the upstream pier was submerged in water, while the downstream one was emerged. The length of the upstream pier was changed three times to give different submersion ratios. Figure (4) shows the experimental values of maximum scour depth as a ratio of mean water depth, $\left(\mathrm{d}_{\mathrm{s}} / \mathrm{h}\right)$ exp, versus the numerical values, $\left(\mathrm{d}_{\mathrm{s}} / \mathrm{h}\right)$ nu, predicted by the $3 \mathrm{D}$ numerical model for different pier spacing and upstream pier submersion ratio used in this study. It is noticeable the fairly agreement between the experimental and numerical values of maximum scour depth. The correlation coefficient between observed and predicted values is 0.79 . 


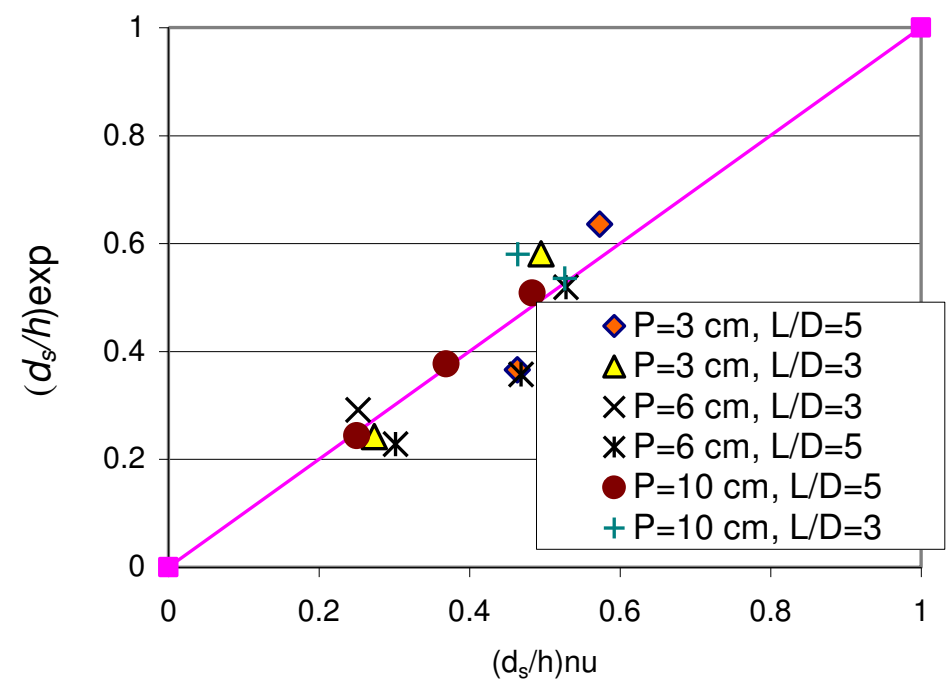

Figure 4 Experimental values of maximum scour depth versus numerical values for two tandem piers at different upstream pier submersion and spacing ratios.

\section{RESULTS AND DISCUSSIONS}

In the previous section, the numerical model was verified using the experimental data. Now, the above numerical model is employed to simulate the flow and the local scour around two tandem circular submerged emergent cylinders. In the numerical simulation the variables are kept the same as their counter parts used in the experimental tests.

Effect of Upstream Pier Submersion Ratio $(\mathrm{P} / \mathrm{h})$ on Flow patterns and Local Scour:

Figures. 4(a-c) present the velocity vectors in $\mathrm{z}-\mathrm{x}$ plan at piers centerline for $\mathrm{P} / \mathrm{h}$ values equal to $0.52,0.76$ and 1.0 respectively at the same values of piers diameter, spacing and flow discharge. The vector plots on the upstream side of the submerged cylinder display the characteristics of the horseshoe vortex along with the down flow along the upstream face of the cylinder. At the top of the submerged cylinder, a trailing vortex is formed and the streamlines concentrate above the trailing vortex. Downstream of the submerged cylinder the flow is directed downward causing scour upstream of the unsubmerged cylinder. However, for unsubmerged upstream cylinder (Figure 4c), the flow is directed upward. At the downstream side of downstream cylinder lee-wake vortex is formed for all cases of submerged ratios. 


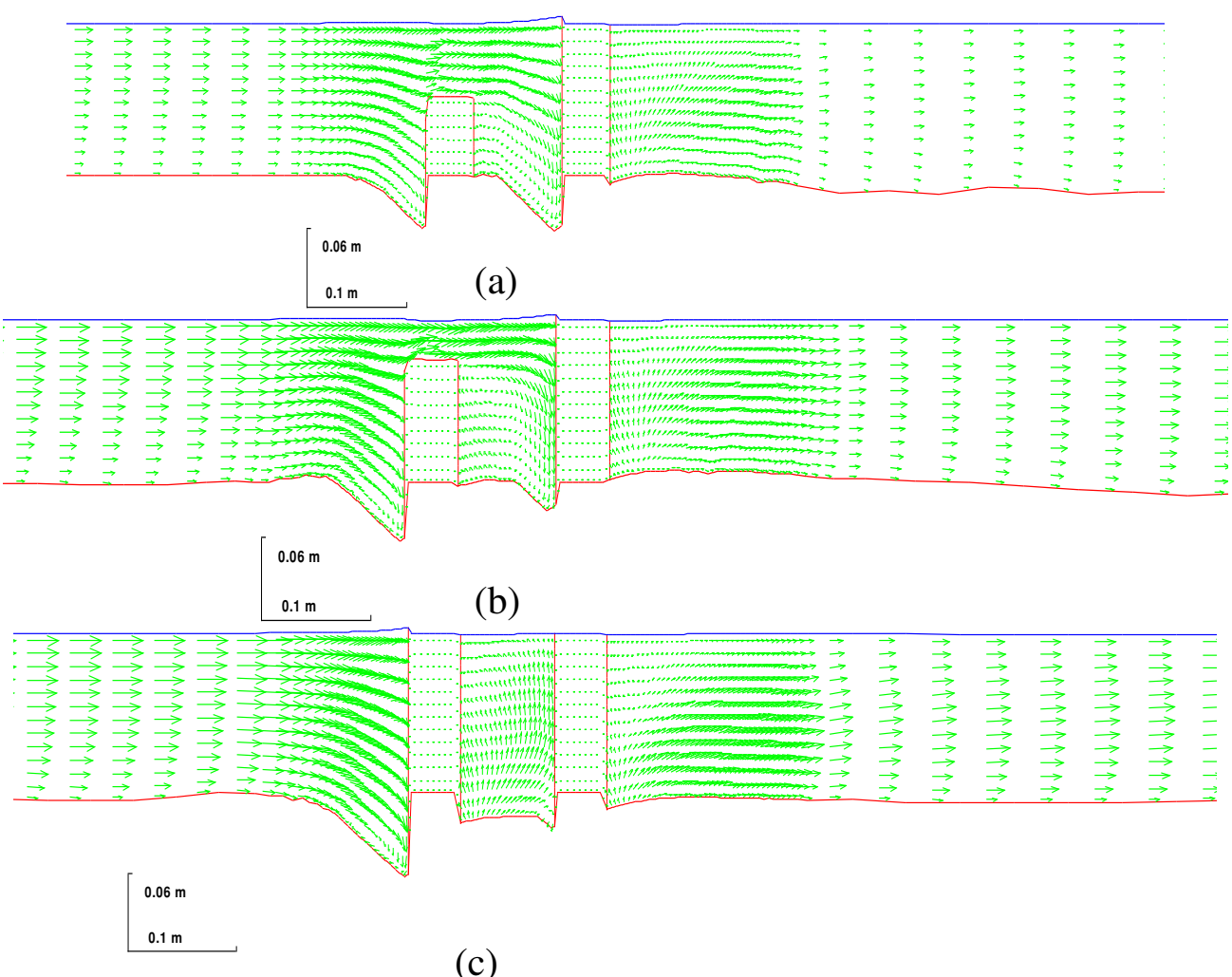

Figure 5 Velocity vectors for piers spacing ratio $(L / D=3)$ at pier diameter $=$ $50 \mathrm{~mm}$, discharge $=9.51 / \mathrm{s}$ and mean upstream water depth $=11.5 \mathrm{~cm}$ at upstream pier submersion ratio $(P / h) 0.52,76$ and 1.0 respectively

In Figures (6-a,b and c), the simulated scour hole bed contours is drawn for two different upstream cylinder submersion ratios and the un-submerged one $(\mathrm{P} / \mathrm{h}=0.52$, 0.76 and 1.0, respectively) where values of discharge, water depth, pier diameter and cylinders spacing ratio (L/D) were kept constant at $9.5 \mathrm{~L} / \mathrm{s}, 11.5 \mathrm{~cm}, 50 \mathrm{~mm}$ and 3 respectively. It is noticeable from these Figures. that scour hole configureurations for two submerged-emergent cylinders differ than that of two unsubmerged cylinders. In Figure 6-a where the upstream cylinder submersion ratio $(\mathrm{p} / \mathrm{h})$ equal 0.52 , there are four different scour holes, the first in the front of upstream cylinder, the second in front of the downstream cylinder however the third and fourth scour holes are formed at left hand side and right hand side of the downstream cylinder and of similar dimensions. Also, we can show that the dimensions of frontal scour holes are small compared with that of side scour holes. By increasing the upstream cylinder submersion ratio to 0.76 as shown in Figure 6-b, the scour hole in front of downstream cylinder disappeared and the dimensions of the two sided scour holes increased and also the maximum scour depth increased. In Figure 6-c for two unsubmerged cylinders, one scour hole is formed in front of the upstream cylinder and extended to the two sides of cylinders and also the maximum scour depth in front of upstream cylinder and higher than that of submerged cylinder. 


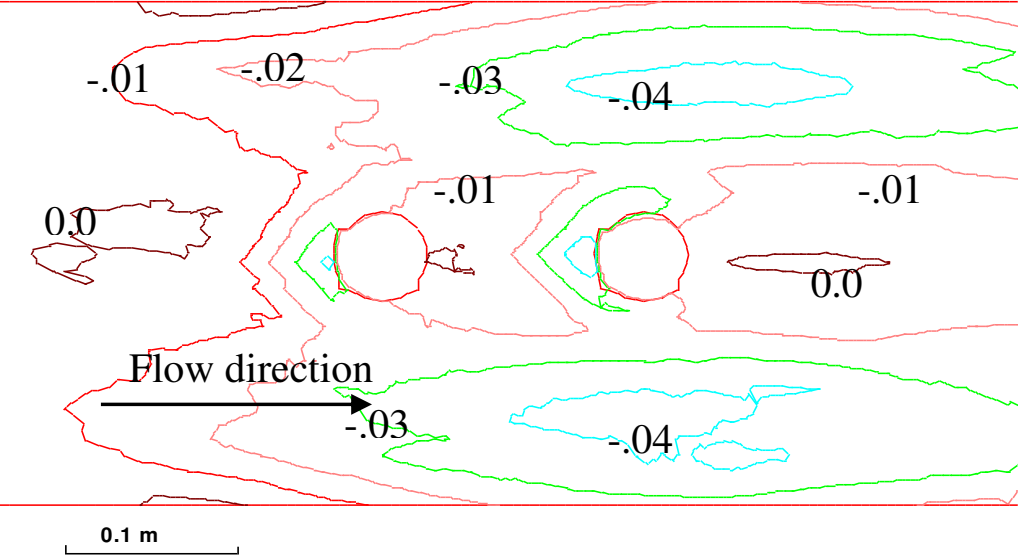

(a) $\mathrm{P} / \mathrm{h}=0.52$

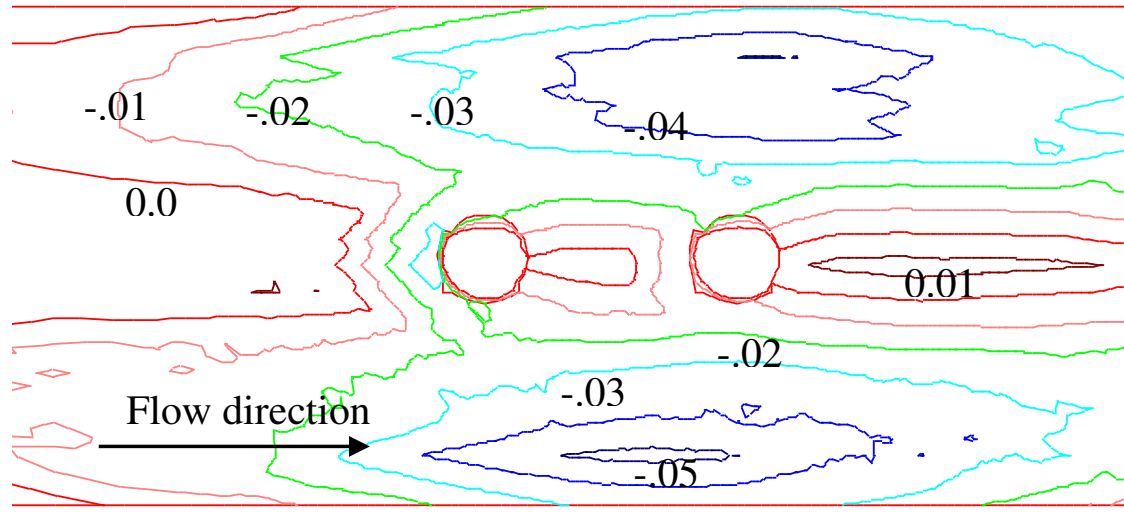

$0.1 \mathrm{~m}$

(b) $\mathrm{P} / \mathrm{h}=0.76$

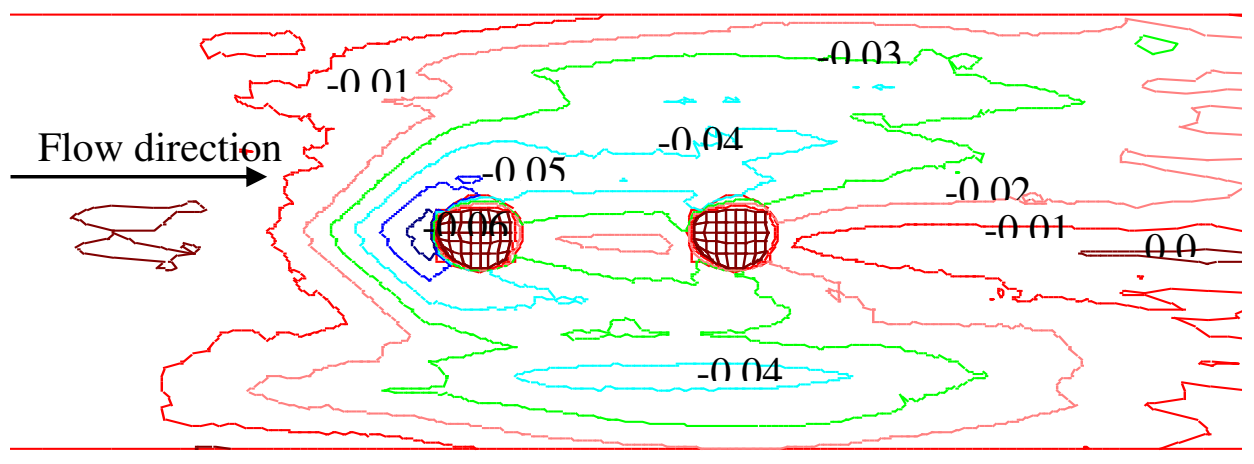

$0.2 \mathrm{~m}$

(c) $P / h=1$

Figure 6 Bed profiles for piers spacing ratio $(L / D=3)$ at pier diameter $=50 \mathrm{~mm}$, discharge $=9.51 / \mathrm{s}$ and mean upstream water depth $=11.5 \mathrm{~cm}$ at upstream pier submersion ratio $(P / h) 0.52,76$ and 1.0 respectively 


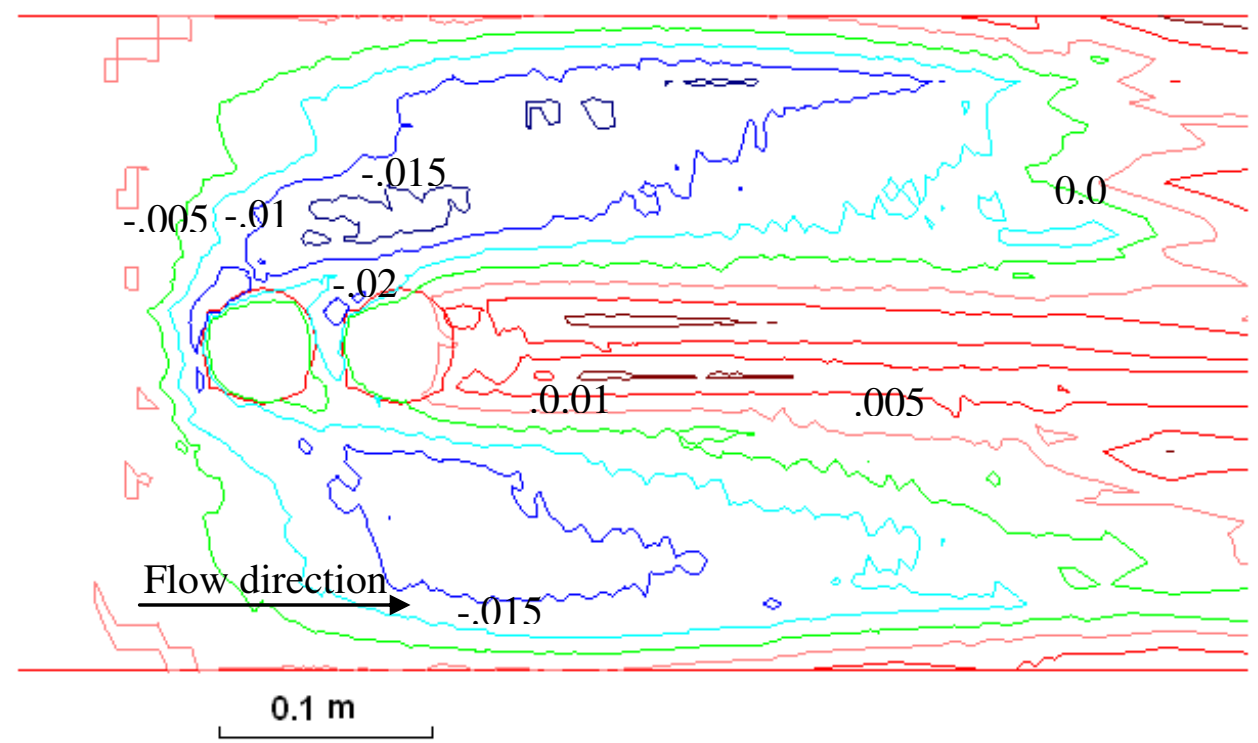

(a) $\mathrm{L} / \mathrm{D}=1.3$

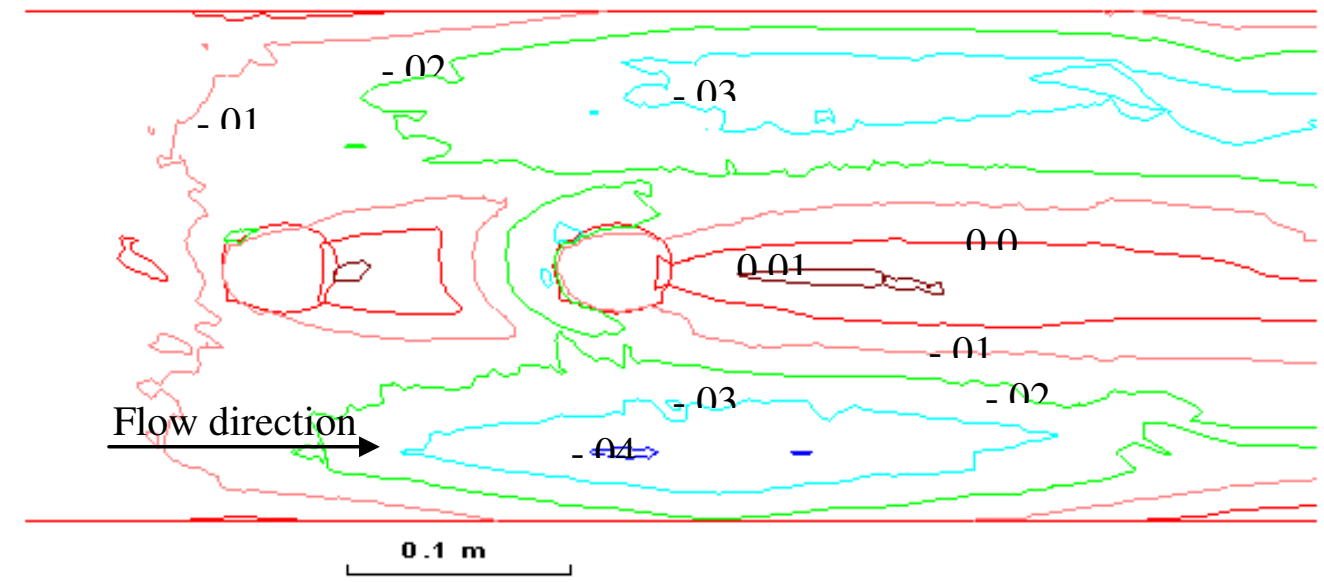

(b) $\mathrm{L} / \mathrm{D}=3.0$

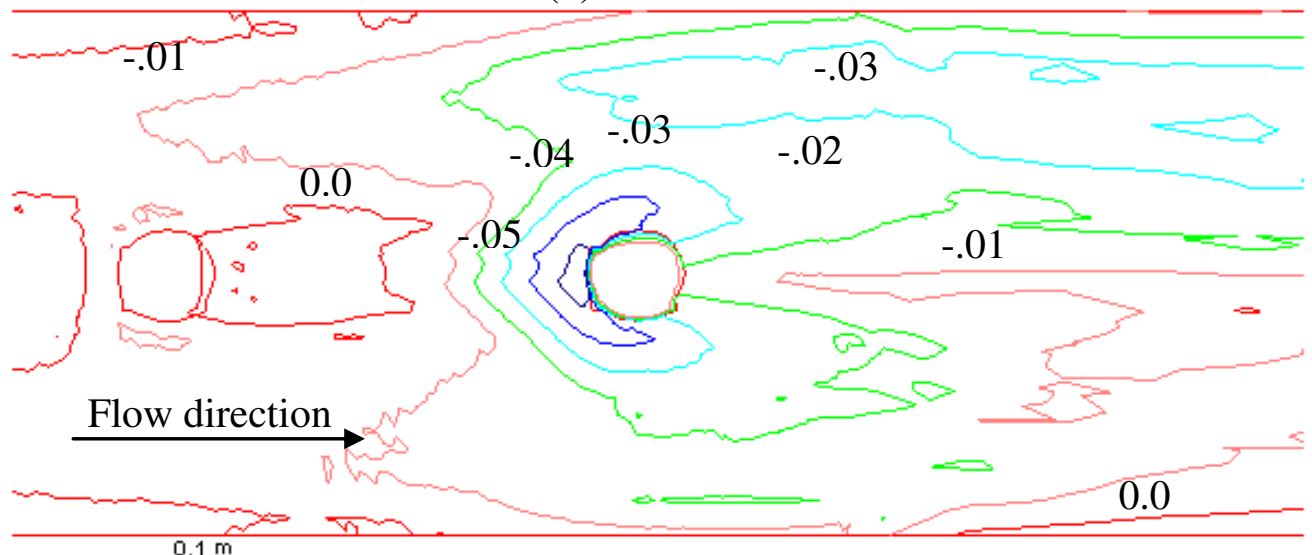

(c) $\mathrm{L} / \mathrm{D}=5$ 
Figure 7 Simulated final bed elevation contours for pier diameter $=50 \mathrm{~mm}$, discharge $=101 / \mathrm{s}$, approach flow depth $=12.8 \mathrm{~cm}$ and upstream pier submersion ratio $=0.36$ at piers spacing $(\mathrm{L} / \mathrm{D})=1.3,3$ and 5 respectively

\section{Effect of Piers Spacing on Flow Patterns and Local Scour:}

Figure (7) shows a comparison between the bed profiles at three cases of piers spacing, $\mathrm{L} / \mathrm{D}=1.3,3$, and $5 \mathrm{~m}$ respectively, for the same discharge, upstream water depth, pier diameter and upstream pier submersion ratio $(P / h)$ as $10 \mathrm{l} / \mathrm{s}, 12.8 \mathrm{~cm}, 50$ $\mathrm{mm}$ and 0.36 , respectively. It is noticeable the difference between the three cases, where the scour hole at $\mathrm{L} / \mathrm{D}=1.3$ is similar to that of unsubmerged piers (Figure 7-a). As the piers spacing increases, the scour hole is divided to four holes (Figures. 7-b, 7c). Also, it can be observed that the maximum scour depth increases by increasing the piers spacing and its position.

Figure (7): Simulated final bed elevation contours for pier diameter $=50 \mathrm{~mm}$, discharge $=10 \mathrm{l} / \mathrm{s}$, approach flow depth $=12.8 \mathrm{~cm}$ and upstream pier submersion ratio $=0.36$ at piers spacing $(\mathrm{L} / \mathrm{D})=1.3,3$ and 5 respectively.

\section{Effect of Piers Diameter on The Scour Process:}

Figure (8) illustrates the bed profiles for piers diameter 30, 50, and $70 \mathrm{~mm}$ respectively. For the three cases the discharge, upstream water depth, upstream pier submersion ratio and piers spacing were kept constant at $9 \mathrm{~L} / \mathrm{s}, 13 \mathrm{~cm}, 0.44$ and 3 respectively. From the figure, the dimensions of scour hole increases by increasing of pier diameter and take uniform shape. 


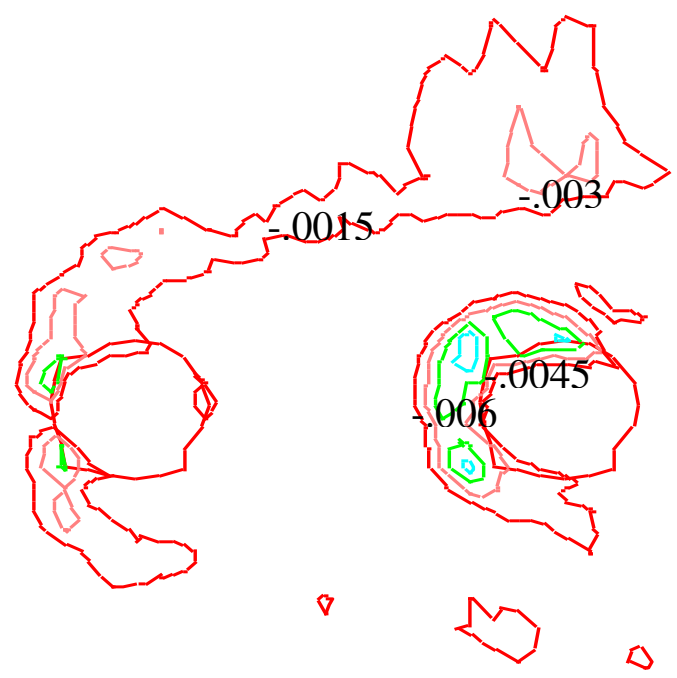

Flow direction

(a): $D=30 \mathrm{~mm}$

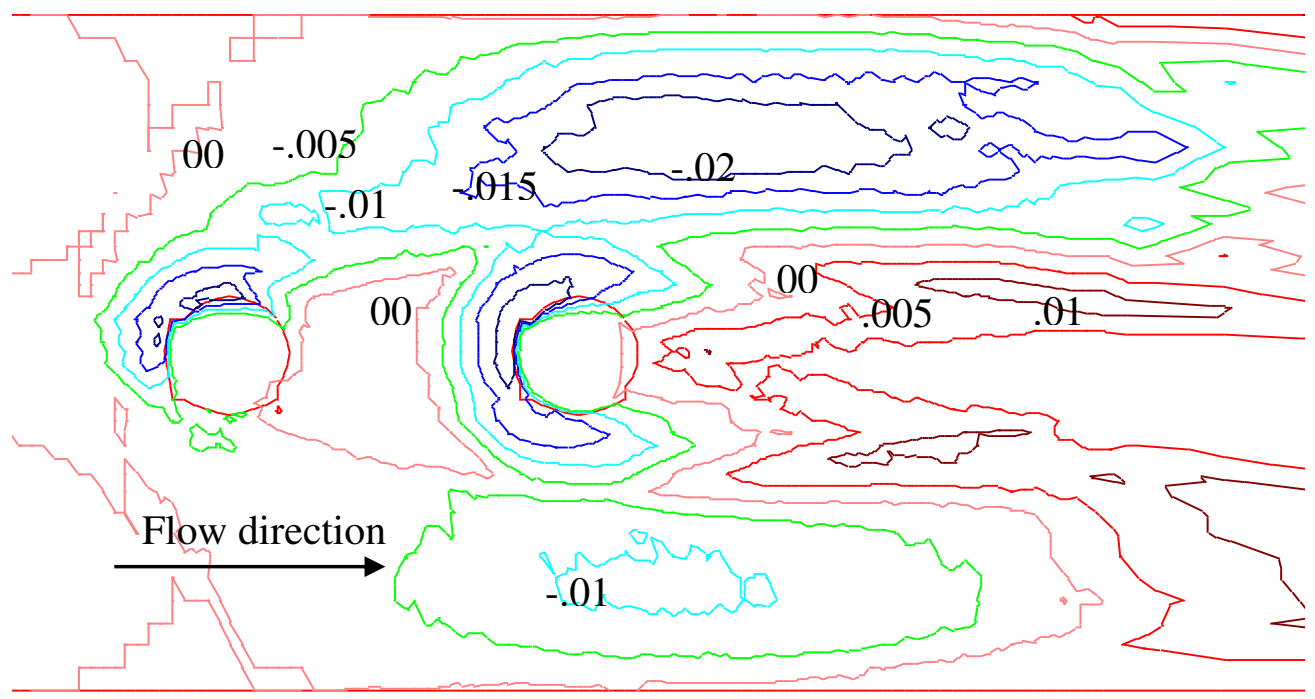

$0.1 \mathrm{~m}$

(b): $D=50 \mathrm{~mm}$ 


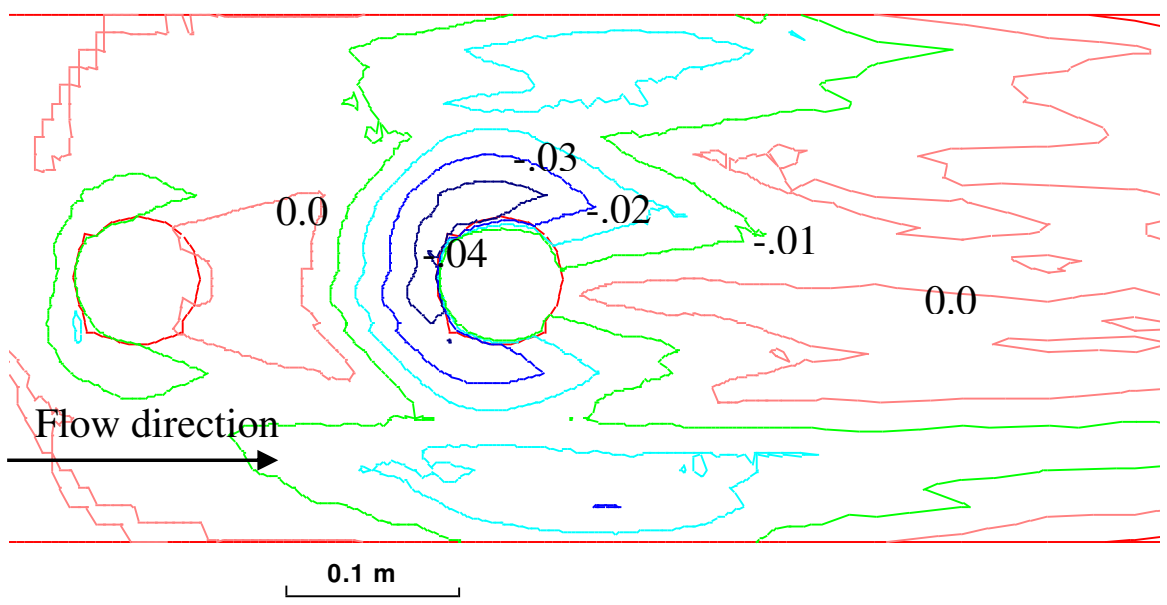

\section{( c ): $\mathbf{D}=\mathbf{7 0} \mathrm{mm}$}

Figure 8 Bed profiles for piers spacing ratio $(\mathrm{L} / \mathrm{D}=3)$, discharge $=9.0 \mathrm{l} / \mathrm{s}$, mean upstream water depth $=13 \mathrm{~cm}$ and upstream pier submersion ratio $(\mathrm{P} / \mathrm{h})$ $=0.44$ at pier diameter 30,50 and $70 \mathrm{~mm}$ respectively

\section{Estimating Maximum Scour Depth:}

To predict the effect of submerged pier ratio on maximum scour, the values of $\mathrm{ds} / \mathrm{h}$ are plotted against $\mathrm{P} / \mathrm{h}$ values for different values of L/D as shown in Figure (9), for circular piers of diameter $50 \mathrm{~mm}$. It is shown that the increase of $\mathrm{L} / \mathrm{D}$ value increases the maximum scour depth at the same $\mathrm{P} / \mathrm{h}$ value. Also, it is seen the decrease of the maximum scour depth with the increase of $\mathrm{P} / \mathrm{h}$ till $\mathrm{P} / \mathrm{h}$ reaches to 0.35 to 0.5 , then the maximum scour depth increases again with the increase of $\mathrm{P} / \mathrm{h}$ value to reach its maximum value at unsubmerged piers.

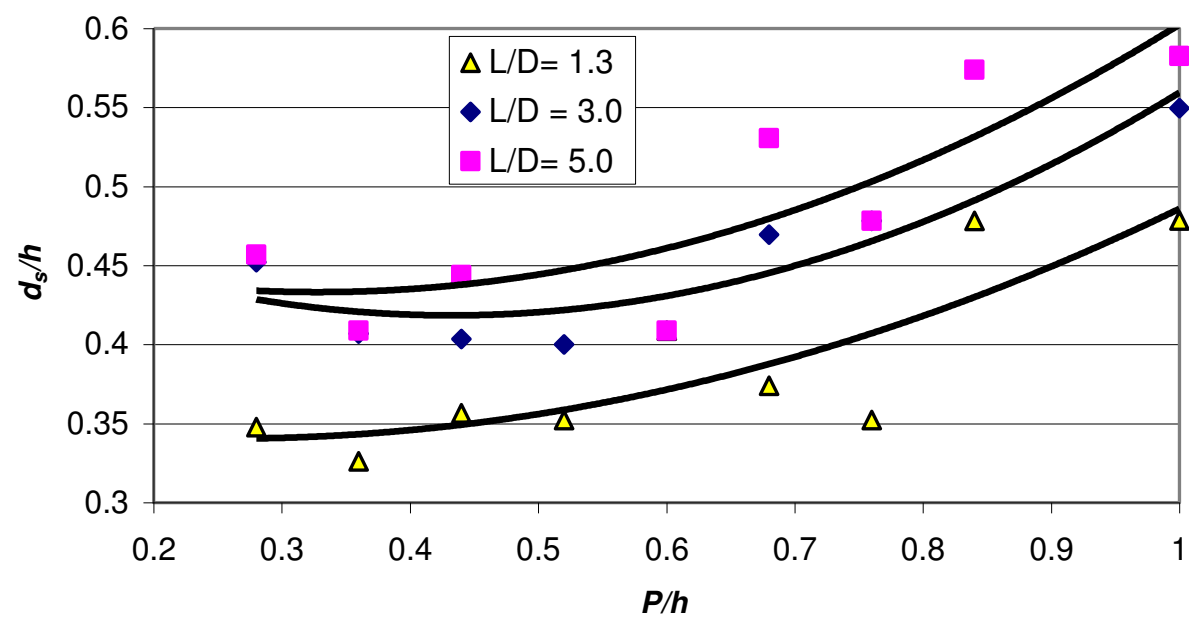

Figure 9 Variation of $d_{s} / h$ with $P / h$ for different values of $L / D$ at pier diameter equal to $50 \mathrm{~mm}$, discharge $9.5 \mathrm{~L} / \mathrm{s}$ and upstream water depth $11.5 \mathrm{~cm}$ 
Figure 10 shows the variation of the maximum scour depth around two submerged- unsubmerged piers with $\mathrm{P} / \mathrm{h}$ values for different piers diameters. It is noticeable that the maximum scour depth increase by increasing the pier diameter. Also, $P / h$ value which gives minimum scour depth increases by increasing piers diameter.

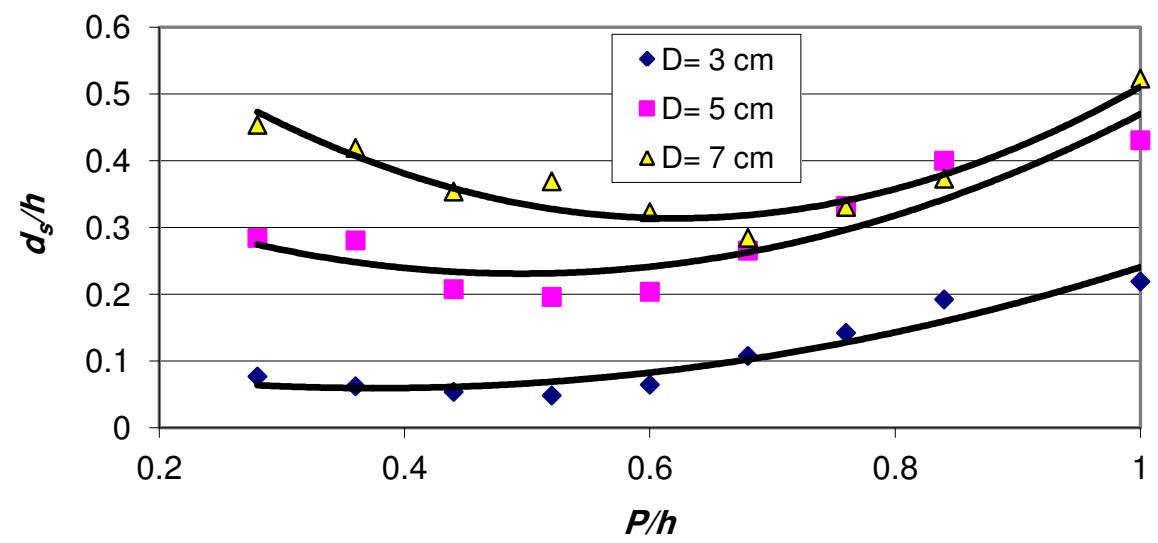

Figure 10 Variation of $d_{s} / h$ with $\mathrm{P} / \mathrm{h}$ with different values of pier diameter at piers spacing ratio L/D equal to 3 , discharge $9.0 \mathrm{~L} / \mathrm{s}$ and upstream water depth 13 $\mathrm{cm}$

The maximum scour depth around two submerged un-submerged piers is significantly dependent on upstream pier submerged ratio $(\mathrm{P} / \mathrm{h})$ as shown in Figures. (9) and (10), spacing between the two piers (L/D), densimetric Froude number, $F_{e s}=U / \sqrt{\frac{\rho_{s}-\rho}{\rho} g d_{90}}$, and ratio of pier diameter to channel width. A multi-linear regression analysis is used to correlate the different parameters and deduce an empirical equation for computing the maximum scour depth (Eqn. 15) due to the interaction between submerged and emergent piers, where the symbols as defined before. The correlation coefficient between observed and predicted values using equation 15 is 0.84 .

$$
d_{s} / h=0.85 \frac{L}{D}^{0.235} \quad \frac{P}{h}^{0.38} F_{e s}^{3.85} \frac{B}{D}^{-1.75}
$$

\section{CONCLUSIONS}

The main conclusions drawn from this study can be summarized as follows:

1- Flow and local scour around two submerged unsubmerged piers have been modeled using 3D numerical model and many parameters which are very difficult to be measured experimentally can be computed using the model, such as the bed shear stress distribution, velocity vectors. 
2- The maximum scour depth at two submerged unsubmerged piers is largely affected by the ratio of pier diameter to channel bed width, longitudinal spacing between piers, densimetric Froude number and submerged pier submersion ratio.

3- The maximum scour depth decreases by increasing submerged pier height and nearly at mid water depth height begin to increase by increasing submerged pier height.

4- The maximum scour depth for submerged emergent piers is smaller than that of two unsubmerged piers.

5- Empirical equation correlating the different parameters have been developed for approximate computation of maximum scour depth due to the interaction between submerged unsubmerged piers.

\section{REFERENCES}

[1] Dey, S.; Raikar, R. V.; and Roy, A. (2008). "Scour at submerged cylindrical obstacles under steady flow.", J. Hydraul. Eng., ASCE, 134(1), 105-109.

[2] Zhao, M.; Cheng, L.; and Zang, Z. (2010). "Experimental and numerical investigation of local scour around a submerged vertical circular cylinder in steady currents.", Coastal Eng., 57, 709-721.

[3] Palau-Salvador, G.; Stoesser, T.;and rodi, W. (2008). "LES of the flow around two cylinders in tandem", Jour. of Fluids and Structures, 24, 1304-1312.

[4] Stoesser, T.; Palau-Salvador, G., Rodi, W.; and Diplas, P. (2009). "Large eddy simulation of turbulent flow through submerged vegetation", transp. Porous Med., 78, 347-365.

[5] Hsu, T.; Hsieh, C.; and Hwang, R. R. (2004). "Using RANS to simulate vortex generation and dissipation around impermeable submerged double breakwaters", Coastal Eng., 51, 557-579.

[6] Lee, K.; and Mizutani, N. (2008). "Experimental study on scour occurring at a vertical impermeable submerged breakwater", applied Ocean Research, 30, 92-99.

[7] Yasunori, M. (2007). "Local scour and bed evolution around a submerged cylindrical pier.", Annual J. Hydraul. Eng., JSCE, 51, 709-714.

[8] Sadeque, M. A. F.; Rajartnam, N.; and Loewen, M. (2008). "Flow around cylinders in open channels.", J. Eng. Mech., ASCE, 134(1), 60-71.

[9] Sadeque, M. A. F.; Rajartnam, N.; and Loewen, M. (2009). "Effect of bed roughness on flow around bed-mounted cylinders in open channels.", J. Eng. Mech., ASCE, 135(2), 100-110.

[10]Sadeque, M. A. F.; Rajartnam, N.; and Loewen, M. (2009). "Shallow turbulent wakes behind bed-mounted cylinders in open channels.", J. Hydr. Res., 47(6), 727743.

[11]Euler, T.; and Herget, J. (2011). "Obstacle-Reynolds-number based analysis of local scour at submerged cylinders", J. Hydr. Res., 49(2), 267-271.

[12]Amini, A.; Melville, B. W.; Ali, T. M.; and Ghazali, A. H. (2012). "Clear-Water local scour around pile groups in shallow-water flow", Jour. of Hydr. Eng., 138(2), 177-185.

[13]Zhao, M.; Zhu, X.; Cheng, L.; and Teng, B. (2012). "Experimental study of local scour around subsea caissons in steady currents", Coastal Eng., 60, 30-40. 
[14]Shamloo, H.; Rajaratnam, N.; and Katopodis, C. (2001). "Hydraulics of simple habitat structures", J. Hydr. Res., 39(4), 351-366.

[15]Richardson, J. E. and Panchang, V. G. (1998). "Three-dimensional simulation of scour-induced flow at bridge piers." J. of Hydraulic Engineering, ASCE, 124, 530540.

[16]Abouzeid, G.; Mohamed, H. I.; and Ali, S. M. (2007). "3-D numerical simulation of flow and clear water scour by interaction between bridge piers.", J. of Eng. Sciences, Assiut Uinversity, Egypt, 35(4), 891-907.

[17]Tseng, M. H., Yen, C. L. and Song (2000). "Computation of three-dimensional flow around square and circular piers." Int. Jour. Numerical Methods in Fluids, 34, 207-227.

[18]Yen C. L., Lai, J. S. and Chang, W. Y. (2001). "Modelling of 3D flow and scouring around circular piers." Proc. Natl. Sci. Counc., ROC (A), Vol. 25, No. 1, $17-26$.

[19]Olsen, N. R. B., (1996), "A three-dimensional numerical model for simulation of sediment movement in water intakes with multi-block option", SSIIM User Manual Version 1.4.

[20]Olsen, N. R. B., and Kjellesvig, H. M., (1998a), "Three-dimensional numerical flow modelling for estimation of spillway capacity", Jour. of Hydraulic Research, Vol. 36, No. 5.

[21]Olsen, N. R. B., and Skoglund, (1994), "Three-dimensional numerical modelling of water and sediment flow in a sand trap", Jour. of Hydraulic Research, 32, 833844.

[22]Olsen, N. R. B. and Kjellesvig, H. M. (1998). "Three-dimensional numerical flow modeling for estimation of maximum local scour depth." J. of hydraulic Research, IAHR, 36, 579-590.

[23]Olsen, N. R. B., and Stokseth, S., (1995), "Three-dimensional numerical modelling of water flow in a river with large bed roughness." Jour. of Hydraulic Research, 33, 571-581.

[24]Patankar, S. V., (1980), "Numerical heat transfer and fluid flow", McGraw-Hill, New York.

[25]Rodi, W., (1980), "Turbulence models and their application in hydraulics- a state of the art review", IAHR: Delft.

[26]Melaaen, M. C., (1992), "Calculation of fluid flows with staggered and nonstaggered curvilinear non-orthogonal grids-the theory", Numerical Heat Transfer, Part B, 21, 1-19.

[27]Schlichting, H., (1960), "Boundary layer theory", McGraw-Hill, New York.

[28]Van Rijn, L. C. (1987). "Mathematical modeling of morphological processes in the case of suspended sediment transport." Ph.D thesis, Delft Univ. of Tech., Delft, The Netherlands. 


\section{التمثيل العددي للسريان والنحر الموضعي حول دعامتين متجاورتين إحداهما مغمورة والأخرى غير مغمورة}

يقدم هذا البحث دراسة عددية باستخدام نموذج رياضي ثلاثي الأبعاد لتحليل السريان حول دعامتين اسطوانيتين،

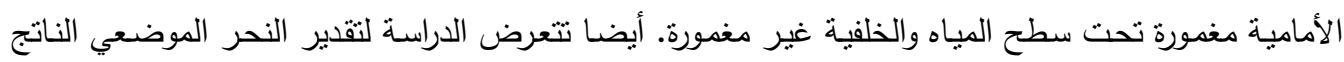

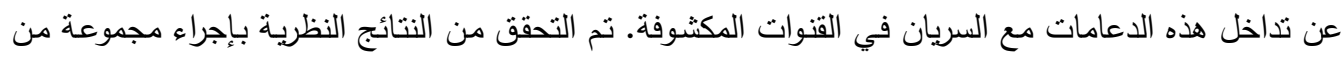

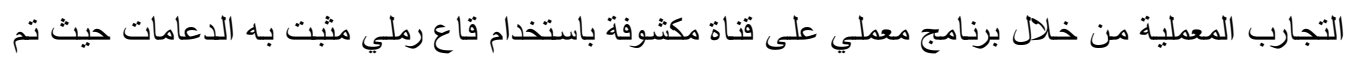

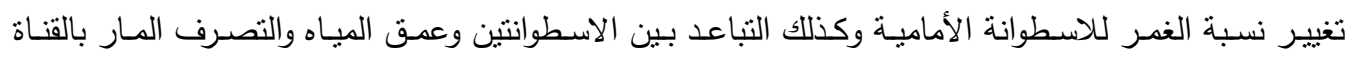
المكثوفة.

طريقة الحجوم المحددة (Finite Volume)، استخدمت في حل معادلات السريان navier Stokes) (k-ع) حيث أنه قد تم استخدام نموذج (orthogonal grid) على شبكة تربيعية في الثلاث أبعان (Equations)

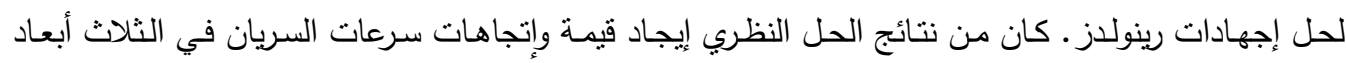

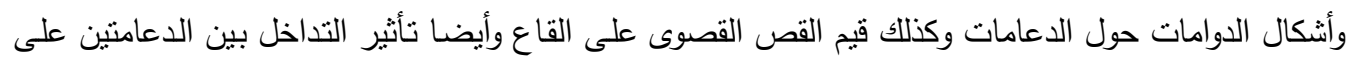

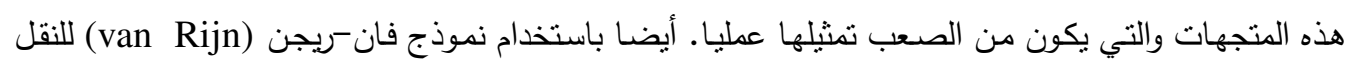

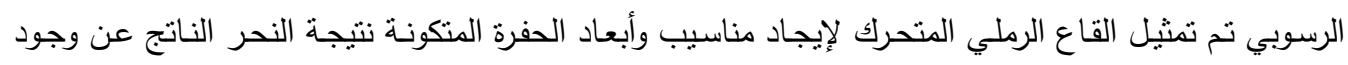

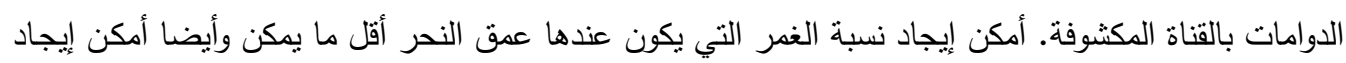

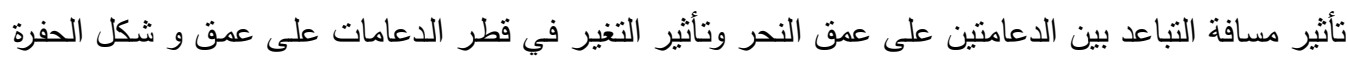

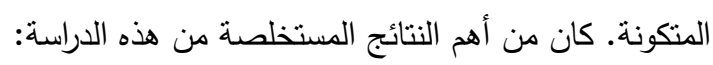

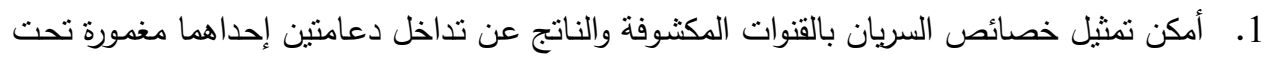

سطح المياه والأخرى غير مغمورة والسريان المنظظم بهذه القنوات والذي يصعب تمثيله عمليا.

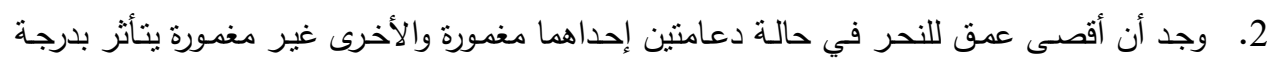

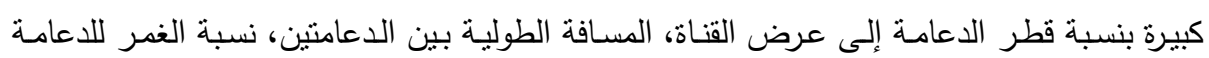
المغمورة و أيضا رقم فرويد كدالة في القطر المتوسط لحبيات القبات القاع. 3. أقصى عمق للنحر يقل مع زيادة نسبة الغمر حتى يصل لحد يبدأ عنده في الزيادة مرة أخرى مع زيادة نسبة الغمر.

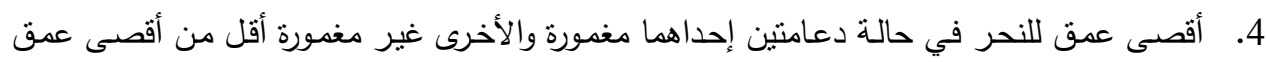
للنحر عندما تكون كلا الدعامتين غير مغمورة.

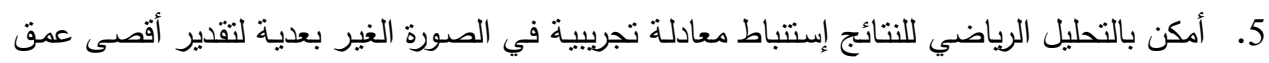
للانحر في حالة دعامتن إحداهما مغمورة والأخرى غير مغمورة. 